\title{
Role of nucleolar organiser regions in differentiating malignant from benign tumours of the colon
}

\author{
P Yang, G S Huang, X S Zhu
}

\begin{abstract}
An argyrophilic technique (AgNOR) was applied to paraffin wax sections of 12 tubular adenomas, 17 villous adenomas with moderate and severe atypia, and 21 colonic adenocarcinomas. The range of the mean number of nucleolar organiser regions (NORS) per nucleus was 1.54-3.28 (99\% CI 2.29-3.04) for tubular adenomas $3.07-4 \cdot 36(2 \cdot 98-4 \cdot 43)$, and 3.60-5.02 (3.744.69) for villous adenomas with moderate and severe atypia, respectively, and 5.53$9.33(6 \cdot 15-8 \cdot 54)$ for highly differentiated adenocarcinomas. The number of AgNORs permitted differentiation among the three groups. The differences observed were significant. Malignant tumour cells were characterised by a large number of AgNORs which were small in size and showed a scattered distribution. Nuclei of tubular adenoma and villous adenoma with moderate atypia had only a small number of large sized AgNORs in a clustered distribution.

It is suggested that this method distinguishes malignant epithelial cells from benign cells of colon, even those with severe atypia, and that it is a useful adjunct to diagnostic histopathology.
\end{abstract}

Tubular adenomas are the commonest tumour of the large bowel; villous adenomas are rare, but the incidence of invasive carcinoma in villous adenoma is high, and it is difficult to differentiate villous adenomas with atypia from adenocarcinomas. Immunohistochemical techniques are often used in difficult cases, yet many remain unresolved.

Nucleolar organiser regions (NORs) are loops of DNA in the nuclei of cells which possess ribosomal RNA genes. These are transcribed by RNA polymerase. ${ }^{1}$ The AgNOR method stains NOR associated proteins and changes in NOR distribution-for example, an increased number is associated with an increased ribosomal transcriptional activity. ${ }^{2} \mathrm{~A}$ recent study showed that the reaction can be applied to routinely processed paraffin wax tissue sections. ${ }^{3}$ The use of the AgNOR technique in paraffin wax sections of tumours was recently described for assessment of grades of malignancy of lymphomas, ${ }^{4}$ melanotic skin lesions, ${ }^{5}$ breast tumours, ${ }^{6}$ small cell carcinoma of the lung, ${ }^{7}$ small cell tumours of childhood ${ }^{8}$ malignant mesothelial cells, ${ }^{9}$ and fibrosarcoma. ${ }^{10}$
We therefore applied this technique to three groups of benign and malignant tumours of colon to try to assess its value in differentiating among these tumours. The aim of this work was to determine whether this simple and rapid AgNOR technique would help to distinguish between villous adenomas with severe atypia and adenocarcinoma. ${ }^{11}$

Fifty specimens from the same number of patients were examined. These comprised 12 tubular adenomas, 17 villous adenomas (including six with moderate atypia and 11 with severe atypia), and 21 adenocarcinomas (including 10 villous adenocarcinomas and 11 tubular adenocarcinomas). The tissues studied had been previously diagnosed on the basis of routine haematoxylin and eosin stains. Atypia can be graded according to Morson ${ }^{12}$ as moderate or severe on the basis of nuclear changes such as enlargement, pleomorphism, loss of polarity, stratification and an increase in the number of mitotic figures, some of which may be abnormal forms. These features of atypia in villous adenomas vary in severity not only in different tumours but also within the same tumour.

Tissues were fixed in $10^{\circ}$, formalin solution and processed to paraffin wax. Sections were cut at $3 \mu \mathrm{m}$ thickness and submitted to AgNOR staining with slight modification. ${ }^{4}$ Briefly, sections were dewaxed and taken to water. The reaction mixture was made by dissolving gelatin in $1^{\circ}$ o aqueous formic acid to make a $1^{\circ}{ }_{0}$ solution. This was mixed with $50 \%$ aqueous silver nitrate solution in a proportion of $1: 2$. Sections were incubated at room temperature in this mixture for 45 minutes, washed with tap water, taken to xylene and mounted.

The AgNORs were seen as dots within the cell nuclei and counted using a $\times 100$ oil immersion lens without previous knowledge of the histological diagnosis. Fields were selected at random and 100 cells were examined using a graticle to prevent recounting. Discrete black dots and dispersed AgNORs in the nuclei were counted and the mean number per nucleus calculated. Student's $t$ test for unpaired data and calculation of $99 \%$ confidence interval (CI) was used for statistical analysis.

\section{Results}

\section{TUBULAR ADENOMAS}

The mean number of AgNORs per nucleus was 2.67 (range $1.54-3.28,99 \%$ CI $2 \cdot 29-3.04$ ) (fig 1). The AgNORs were small; a large nucleolus was also visualised and this was counted as one AgNOR. 
Figure 1 Adenomatous polyp. Most nuclei possess only several AgNORs (mean 2.67).

Figure 2 Villous adenoma with moderate atypia. Many black dots are present in each nucleus, with barely discernible clustered AgNORs constituting an AgNU (mean 3.71 ).
Figure 3 Villous adenoma with severe atypia. Many cells contain small uniform nuclear AgNORs (mean 4.22).
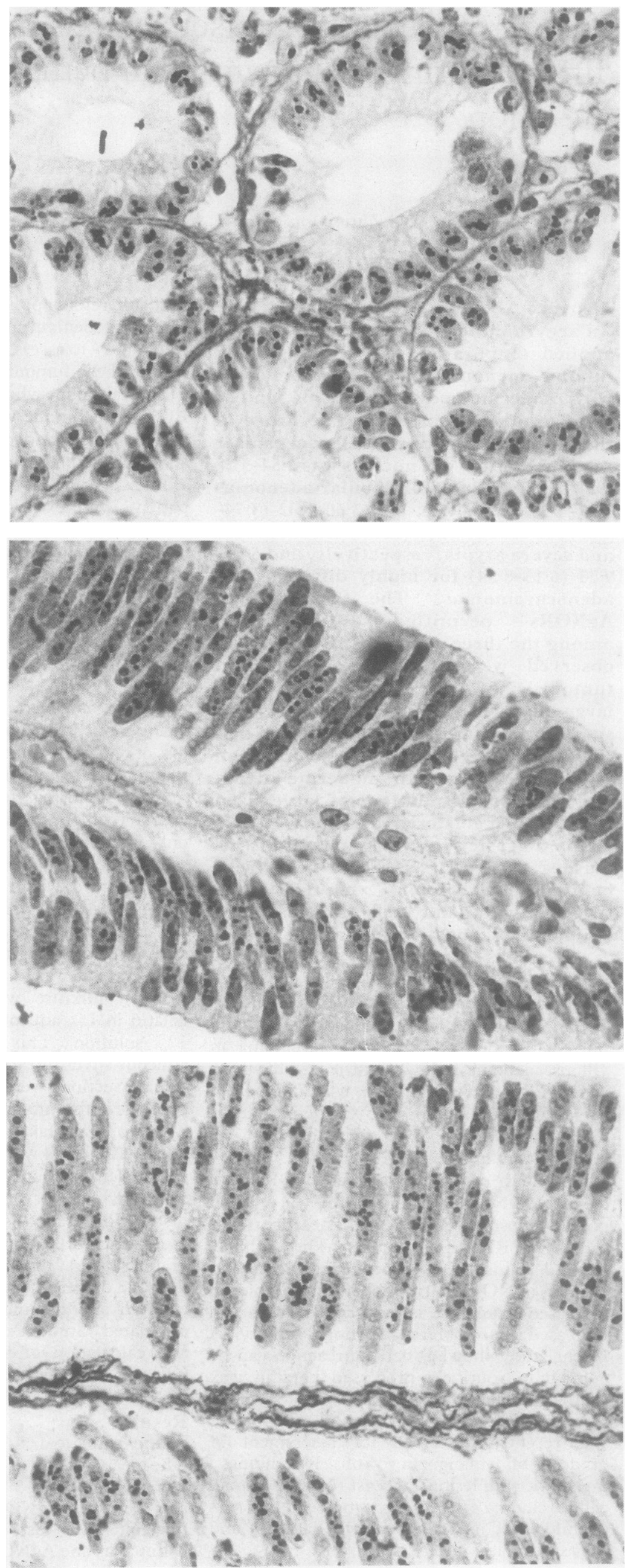


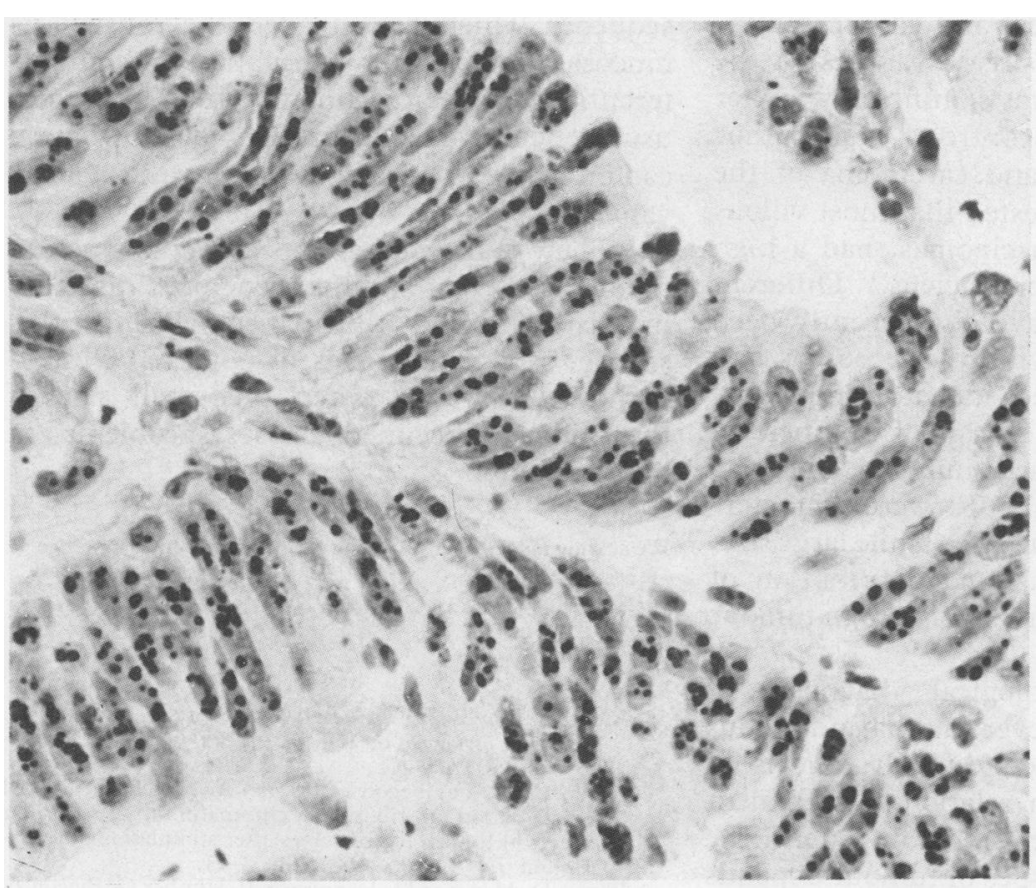

Figure 4

Adenocarcinoma: most cells contain numerous AgNORs which are uniformly small (mean 7.35).

\section{VILLOUS ADENOMAS}

Villous adenomas (six with moderate atypia and 11 with severe atypia) were examined and the mean number of AgNORs per nucleus was 3.71 (range $3 \cdot 07-4 \cdot 36,99 \%$ CI $2.98-4.43$ ) and 4.22 (range $3.60-5 \cdot 02$, 99\% CI 3.74-4.69), respectively (figs 2 and 3). The AgNORs were arranged in one or more clusters, or occurred as individual "satellites".

\section{ADENOCARCINOMAS}

Neoplastic cell nuclei contained a mean of $7 \cdot 35$ AgNORs (range 5.53-9.33, 99\% CI 6.158.54). The AgNORs were small and uniform and scattered in a large irregularly shaped zone in the cell nucleus (fig 4). The overall results are summarised in the table and in fig 5 .

\section{Discussion}

NORs are located on each of the short arms of

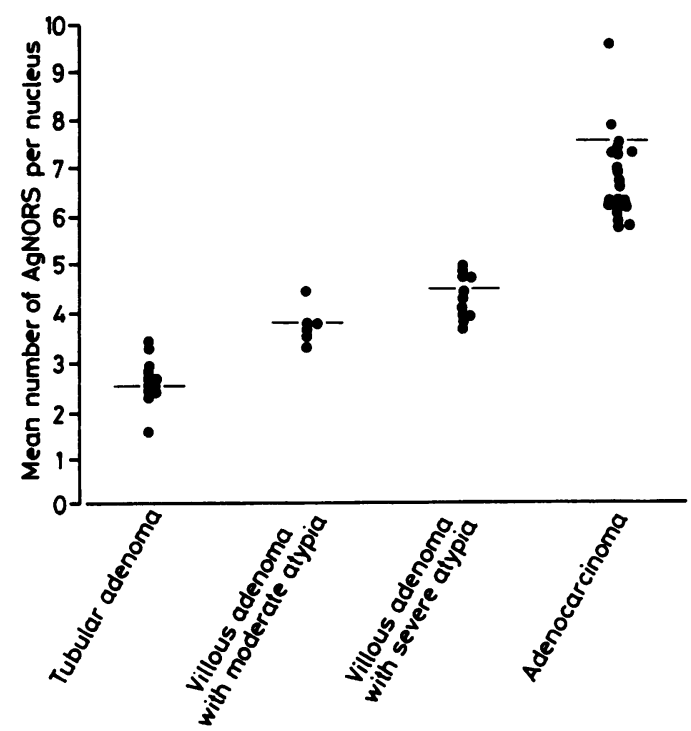

Figure 5 Mean number of AgNORs per nucleus in different groups.

chromosomes 13, 14, 15, 21 and $22 .{ }^{1314}$ The silver staining technique identifies non-histonuclear proteins associated with the sites of rRNA transcription. The technique was modified recently, permitting much more rapid staining by means of a one step method. ${ }^{15}$ Most recently, the method was adapted again by lowering the temperature for the reaction from the usual $60^{\circ} \mathrm{C}$ to $20^{\circ} \mathrm{C}^{3}$

Using this improved technique, many AgNOR sites have been observed in certain malignant and benign lesions. ${ }^{4-10}$ The differences between benign and malignant NORs in terms of their size, number, and distribution inside the nucleus were so striking that a statistical evaluation of these differences is almost superfluous. It is clear that an increase in AgNOR count can be seen in actively proliferating cells due to increased transcriptionally active ribosomal sites.

To investigate further AgNORs in human malignant and benign tissues, Mamaev et al used the AgNOR technique to examine 30

Mean number of nucleolar organiser regions stained in each specimen examined

\begin{tabular}{|c|c|c|c|c|}
\hline \multicolumn{2}{|c|}{ Tubular adenoma } & \multirow{2}{*}{$\begin{array}{l}\begin{array}{l}\text { Villous adenoma with } \\
\text { moderate atypia }\end{array} \\
3.83 \\
3.76 \\
3.45 \\
3.80 \\
3.07 \\
4.36\end{array}$} & \multirow[b]{2}{*}{$\begin{array}{l}\text { Villous adenoma with } \\
\text { severe atypia } \\
3.60 \\
3.72 \\
3.88 \\
4.71 \\
4.02 \\
3.93 \\
4.85 \\
4.32 \\
4.45 \\
5.02 \\
3.87\end{array}$} & \multirow[b]{2}{*}{$\begin{array}{l}\text { Adenocarcinoma } \\
6.38 \\
5 \cdot 98 \\
6 \cdot 18 \\
5 \cdot 80 \\
6 \cdot 23 \\
7 \cdot 80 \\
7 \cdot 88 \\
7 \cdot 28 \\
7 \cdot 80 \\
5 \cdot 53 \\
7.08 \\
6.96 \\
6.05 \\
5.90 \\
9 \cdot 33 \\
7 \cdot 15 \\
6.81 \\
5.96 \\
6.56 \\
5.91 \\
6.01\end{array}$} \\
\hline $\begin{array}{l}1 \cdot 54 \\
2.62 \\
2.90 \\
2.55 \\
2.46 \\
2.51 \\
3.25 \\
3 \cdot 28 \\
2.62 \\
2 \cdot 77 \\
2.71 \\
2 \cdot 82\end{array}$ & & & & \\
\hline $\begin{array}{l}\text { Mean } \\
\text { SD } \\
\text { SEM } \\
99 \% \text { CI }\end{array}$ & $\begin{array}{l}2 \cdot 67 \\
0 \cdot 44 \\
0 \cdot 13 \\
2 \cdot 29-3 \cdot 04\end{array}$ & $\begin{array}{l}3 \cdot 71 \\
0 \cdot 43 \\
0 \cdot 18 \\
2 \cdot 98-4 \cdot 43\end{array}$ & $\begin{array}{l}4 \cdot 22 \\
0 \cdot 48 \\
0 \cdot 15 \\
3 \cdot 74-4 \cdot 69\end{array}$ & $\begin{array}{l}7 \cdot 35 \\
1 \cdot 89 \\
0 \cdot 42 \\
6 \cdot 15-8 \cdot 54\end{array}$ \\
\hline
\end{tabular}


patients with oesophageal and gastric carcinomas. The content of silver granules in the nuclei of tumour cells was significantly higher than in those of normal controls. ${ }^{16}$ The author also studied adenoma and carcinoma of the colon. The results suggested that most villous adenomas, like adenocarcinomas, had a high content of AgNORs per nucleus. ${ }^{17}$ Different distribution patterns have also recently been determined between hyperplastic polyps and adenomatous polyps and adenocarcinomas of human intestine, on the basis of numbers of AgNORs. Small size, large number, and scattered distribution of AgNORs were characteristic of malignant tumour cells, while large size, small number, and clustered distribution of AgNORs were characteristic of benign tumour cells. ${ }^{18}$

The accurate histological diagnosis of villous adenoma with severe atypia and villous adenocarcinoma is often difficult, but is of essential importance in relation to treatment and prognosis. To a considerable extent, the differentiation of two types of tumour depends on the experience of pathologists. ${ }^{11}$

In our study most tubular adenomas cells possessed only a few AgNORs per nucleus; villous adenoma with moderate or severe atypia showed more AgNORs and adenocarcinoma the greatest number of AgNORs. There was a significant difference between adenomatous polyps and villous adenomas and highly differentiated adenocarcinomas $(p<0.001)$. Furthermore, no overlap of mean number of AgNORs was found between the individual cases in benign and malignant groups. In spite of there being no significant difference between villous adenoma with moderate atypia and with severe atypia, as a whole, villous adenoma still possessed more AgNORs than tubular adenomas. Villous adenomas had a much higher proliferative activity.

The chacteristic distribution of AgNORs in benign and malignant tumours was similar to that described by Derenzini. ${ }^{18}$ Unlike the results reported by Mamaev, ${ }^{17}$ however, our study has shown that the AgNOR staining method can readily distinguish between highly differentiated adenocarcinomas and villous adenomas, even those with severe atypia. This may be because the villous adenomas studied by Mamaev had more potential for malignancy as most of the epithelial cells had characteristics of carcinoma in situ; some had even invaded muscularis mucosae. ${ }^{17}$ For this reason it is best to restrict the use of the word villous adenoma to the stage of the adenoma-carcinoma sequence which has invaded the muscularis mucosae and the submucosal tissues. The differentiation or maturation in a tumour are not usually heterogeneous throughout and what we can measure by our method is only the average values.

In view of the similar appearance and size of the two cell types and the recognised difficulty in distinguishing them histologically, this simple, rapid, method is of potential clinicopathological value, when thi small size of the biopsy specimen causes problems in interpretation.

We acknowledge Ms Y Y Zhang for photographic assistance.

1 Albert B, Bray D, Lewis J, Raff M, Roberts K, Watson JD. Molecular biology of the cell. New York: Garland Publishing Inc, 1983:424-6.

2 Derenzini M, Farabegoli F, Pession A, Novello F. Spatial redistribution of ribosomal chromatin in the fibrillar centers of human lymphocytes after stimulation of transcription. Exp Cell Res 1987;130:31-41.

3 Ploton D, Menager M, Jeannesson P, Himber G, Pigeon F, Adnet JJ. Improvement in the staining and in the visualisation of the argyrophilic proteins of the nucleolar organiser region at the optical level. Histochem $J 1986 ; 18$ : 5-14.

4 Crocker J, Nar P Nucleolar organizer regions in lymphomas. J Pathol 1987;151:111-8.

5 Crocker J, Skilbeck N. Nucleolar organizer regions associated proteins in cutaneous melanotic lesions: a quantitative study. $J$ Clin Pathol 1987;40:885-9.

6 Smith R, Crocker J. Evaluation of nucleolar organizer region-associated proteins in breast malignancy. Histopathol 1988;12:113-25.

7 Crocker J, Ayres J, McGovern J. Nucleolar organizer regions in small cell carcinoma of the bronchus. Thorax 1987;42:972-5.

8 Egan MJ, Raafat F, Crocker J, Smith K. Nucleolar organize regions in small cell tumour of childhood. J Pathol 1987;153:275-80.

9 Ayres JG, Crocker JG, Skilbeck NQ. Differentiation of malignant from normal and reactive mesothelial cells by the argyrophil technique for nucleolar organizer region associated proteins. Thorax 1988;43:366-70.

10 Egan MJ, Raafat F, Crocker J, Smith K. Nucleolar organizer regions in fibrous proliferation of childhood and infantile fibrosarcoma. J Clin Pathol 1988;41:31-3.

11 Morson BC. The large intestine. In: Systemic pathology. Vol 3. Edinburgh: Churchill Livingstone, 1978:1131-3.

12 Morson BC, Dawson IMP. In: Gastrointestinal pathology. Oxford: Blackwell Scientific Publications, 1979:621-2.

13 Anonymous. NORs - a new method for the pathologist. [Editorial.] Lancet 1987; i:1413-4.

14 Stahl A. The nucleolar and nucleolar chromosomes. In: Jordan EG, Cullis CA, eds. The nucleolus. Cambridge: Cambridge University Press, 1982:1-24.

15 Howell WM, Black DA. Controlled silver staining of nucleolus organizer regions with a protective colloida developer: a one-step method. Experientia 1980;36:1014

16 Mamaev NN, Bebia NV, Mamaeva SE, Chalisov IA Bykhovets IV. Evaluation of nucleolar organizer activity in tumor cells from patients with esophageal and gastric carcinoma. Bull Exp Biol Med 1985;99:477-9.

17 Mamaev NN, Mikhailon AA, Irzhanov SI, Bykhovets IV. Nucleolar organizer activity in epithelial tumor cells of the hucleolar organizer activity in epithelial tumor

18 Derenzini M, Romagnoli T, Mingazzini P, Marinozzi V. Interphasic nucleolar organizer region distribution as a diagnostic parameter to differentiate benign from malig nant epithelial tumors of human intestine. Virchows Arch (Cell Pathol), 1988;54:334-40. 